України / С. М. Амеліна, В. А. Гаманюк та ін. - К. : Ленвіт, 2014. - 136 с. 5. Програма 3 англійської мови для професійного спілкування / Г. Є. Бакаєва, О. А. Борисенко, I. I. Зуєнок та ін. - К. : Ленвіт, 2005. - 119 с. 6. Програма 3 англійської мови для університетів (інститутів): п’ятирічний курс навчання / С. Ю. Ніколаєва, М. І. Соловей та ін. / Київ : Британська Рада, Київ. держ. лінгв. ун-т, 2001. - 245 с. 7. Curriculum for English Language development in Universities and Institutes. - Kyiv : British Council, 2001. - 247 p. 8. Curriculum für den sprachpraktischen Deutschunterricht an pädagogischen Fakultäten der Universitäten und pädagogischen Hochschulen. - K. : Ленвіт, 2004. - 256 с.

\title{
ПРОФЕСІЙНА МОБІЛЬНІСТЬ ЯК ОДИН ІЗ КРИТЕРІЇВ ЕФЕКТИВНОСТІ ПІДВИЩЕННЯ КВАЛІФІКАЦІЇ ФАХІВЦІВ
}

Грибова Л. В.Професійна мобільність як один із критеріїв ефективності підвищення кваліфікації фахівців.

У статті, на основі теоретичного осмислення різних наукових підходів, визначено методичні положення щодо тенденцій розвитку професійної мобільності фахівців в умовах ринкової економіки, нестабільної соціальної та політичної ситуацій в Україні. Розкрито економічні, психологічні, соціальні мотиви активізації професійної мобільності у процесі проведення курсів підвищення кваліфікації.

Ключові слова: мобільність, підвищення кваліфікації, додаткова професійна освіта.

Грибова Л. В. Профессиональная мобильность как один из критериев эффективности повышения квалификации специалистов.

В статье, на основе теоретического осмысления разных научных подходов, определены методические положения тенденций развития профессиональной мобильности специалистов в условиях рыночной экономики, нестабильной социальной и политической ситуаций в Украине. Раскрыты экономические, психологические, социальные мотивы активизации профессиональной мобильности в процессе проведения курсов повышения квалификации.

Ключевые слова: мобильность, повышение квалификации, дополнительное профессиональное образование.

Gribova L. V. Professional mobility as one of the criteria for the effectiveness of professional development.

In the article, based upon theoretical apprehension of various scientific approaches the methodological conditions of trends in development of specialists' professional mobility in the context of market economy, unstable social and political situation in Ukraine have been determined. Also some economic, psychological and social motives of facilitating professional mobility during qualification improvement courses have been defined.

Key words: mobility, qualification improvement, extended professional education.

Проблеми професійної мобільності актуалізувались у вітчизняній психології та педагогіці на початку ХХ століття. У 1927 р. у Нью-Йорку П. Сорокін видав працю «Соціальна мобільність», у якій сформулював завдання, основні поняття і принципи дослідження різноманітного руху індивідів у неоднорідному соціальному просторі. 
Мобільність П. Сорокін визначає як перехід, переміщення соціального об'єкта або цінності, створеної або модифікованої завдяки людській діяльності, від однієї соціальної позиції до іншої.

Мета статmі - визначити місце і значення процесу підвищення кваліфікації фахівців будь-яких галузей народного господарства в складній структурі професійної мобільності.

На думку П. Сорокіна, існують два основні типи соціальної мобільності вертикальна і горизонтальна. Вони у свою чергу поділяються на підвиди і підтипи. Під вертикальною мобільністю розуміють ті відносини, що виникають під час переміщення індивіда або соціального об'єкта 3 одного соціального прошарку в інший. Залежно від напряму переміщення вирізняють висхідну мобільність (соціальний підйом, рух угору) і низхідну мобільність (соціальний спуск, рух униз). Між ними існує певна асиметрія: всі прагнуть підніматися і ніхто не хоче опускатися соціальною драбиною. Як правило, висхідна мобільність - явище добровільне, а низхідна - вимушене. Горизонтальна мобільність передбачає перехід індивіда з однієї соціальної групи в іншу, яка розміщена на тому ж рівні.

У сучасних дослідженнях визнано за доцільне розрізняти мобільність структурну та обмінну (циркулюючу). Структурна мобільність зумовлена змінами в економіці і технології виробництва. До таких змін належать індустріалізація, а пізніше зростання значення сфери послуг, скорочення чисельності зайнятих у сільському господарстві, зрушення у структурі професій та робочих місць під впливом сучасної техніки і технології. Поступово скорочується частка порівняно простої трудової діяльності і потреба в ній та збільшується потреба у складній праці. Відповідно зростають вимоги до компетентності та кваліфікації індивідів.

Обмінна мобільність зумовлюється виключно соціальними чинниками. Мається на увазі розширення можливостей здобути вищу освіту, зростання обсягів соціальних гарантій та пільг, що надаються суспільством і державою задля вирівнювання шансів на досягнення економічного і соціального успіху, а також утвердження домінантної структури цінностей і мотивації досягнень [5].

Сучасне українське суспільство існує в умовах некерованої ринкової економіки, нестабільних політичних та соціальних відносин, де діють чинники, які спонукають до мобільності і водночас перешкоджають їй. Істотні відмінності в рівні та якості життя в сільській місцевості та в місті, нерівні стартові можливості молоді, що істотно залежать від рівня життя та матеріального забезпечення їх батьків, послаблення моральних принципів, економічна нестабільність на фоні агресивних інформаційних технологій, які створюють ілюзію необмежених можливостей, спонукає будь-яку людину в будь-якому віці до змін, що і є мобільністю.

Слід зазначити, що у вітчизняних та зарубіжних психолого-педагогічних джерелах проблемам професійної мобільності фахівця присвячено немало наукових праць (О. Архангельський, І. Василенко, Б. Гершунський, Л. Горюнова, В. Горитнько, Е. Зеєр, Л. Зновенко, Є. Іванченко, Б. Ігошев, Ю. Калиновський, С. Капліна, Н. Коваліско, О. Нікітіна, Р. Пріма, П. Ратнікова, П. Сорокін, Л. Сушенцева, У. Сьюел, Н. Таланчук, Р. Тума, В. Улті, П. Хаузера та ін.). Основні підходи до визначення професійної мобільності та їі складників проаналізовано О. Амосовою, С. Батишевим, Ю. Калиновським, І. Мацкуляк, Л. Сушенцевою, В. Томашкевичем, І. Удаловою та ін. Умови формування професійної мобільності розкриті у працях А. Ващенка (майбутніх офіцерів), І. Забірова (керівників промислових підприємств), Є. Іванченко (майбутніх економістів), С. Капліної (майбутніх інженерів), Л. Амірової, І. Нікуліної (викладача вищої школи), Б. Ігошева, О. Нікітіної, Р. Пріми, В. Сластьоніної (майбутнього 
викладача), С. Савицького (фахівця машинобудівного профілю, І. Шпекторенко (державного службовця). Вплив професійної мобільності на професійний розвиток і становлення успішної людини досліджено С. Кугель, Р. Насибуліним, К. Попер, I. Пригожіним, I. Смирновою, I. Фроловим та ін.

Водночас досліджень щодо впливу додаткової професійної освіти на активізацію та конструктивну спрямованість професійної мобільності фахівця практично немає.

Інтенсивність i динамічність змін, що охоплюють всі сфери і процеси життєдіяльності людей, зумовлюють трансформацію ментальних моделей людини у XX1 столітті. Змінюються уявлення людини про взаємодію зі світом, про себе та свою діяльність у цьому світі. Зростають вимоги до особистості, серед яких - вміти аналізувати соціально-економічні тенденції, що постійно змінюються, приймати й реалізувати нестандартні рішення в умовах ринкової конкуренції, усувати стереотипи 3 виробничої та особистісної сфер діяльності, вміти легко адаптуватися до мінливих умов, гнучко взаємодіяти з різними системами і суб'єктами [2, с. 134].

Переважні тенденції соціальної мобільності в Україні зумовлені об'єктивним і суб'єктивним сприйняттям економічних, соціальних, політичних, психологічних змін, що відбуваються в суспільстві протягом останніх 20 років:

- масова примусова, недобровільна міжпрофесійна мобільність зумовлена кризовим станом суспільства в період інституціональних змін, який знижує попит на деякі професії та сприяє виникненню безробіття;

- спадні соціальні переміщення як домінантні тенденції у процесах соціальної мобільності для абсолютної більшості населення;

- зміна професії як складник стратегії виживання;

- примус до самозайнятості без професійної перекваліфікації;

- рух у спадному напрямку суттєво переважає рух у висхідному напрямку;

- стратегії успіху властиві переважно молоді у той час, як для середнього та старшого покоління характерні стратегії виживання.

Підвищення кваліфікації працівників будь-якої галузі, що по суті є додатковою освітою, є невід'ємною частиною неперервною професійної освіти. Вертикальна мобільність певною мірою присутня в будь-якому суспільстві і зумовлює необхідність існування «каналів вертикальної циркуляції», які найбільш повно описав П. Сорокін. У цьому дослідженні доцільно зупинитись на одному з головних каналів соціальної циркуляції, а саме на освіті. Освіта $є$ «соціальним ліфтом», що рухається 3 низів суспільства до його верхів. Одним з інструментів підвищення кваліфікації фахівців $\epsilon$ стимулювання та розвиток професійної мобільності.

Згідно з наказом Міністерства праці та соціальної політики та Міністерства освіти і науки України «Про затвердження Положення про професійне навчання кадрів на виробництві» від 27 березня 2001 року № 127/151, підвищення кваліфікації робітників - це професійно-технічне навчання працівників, що дає можливість розширювати й поглиблювати раніше набуті професійні знання, уміння і навики на рівні вимог виробництва чи сфери послуг.

Підвищення кваліфікації робітників може здійснюватися за такими формами:

- виробничо-технічні курси - призначені для підвищення кваліфікації, поглиблення і розширення знань робітників, їх навичок і вмінь до рівня, що відповідає вимогам виробництва за професією, якою вони володіють. Успішне закінчення курсів $\epsilon$ умовою для призначення робітникам вищого кваліфікаційного розряду (класу, категорії, групи) та професійного зростання;

- курси цільового призначення - робітники вивчають нове обладнання, товари, 
матеріали, послуги, сучасні технологічні процеси, засоби механізації та автоматизації, що використовуються на виробництві, правила та вимоги їх безпечної експлуатації, технічну документацію, ефективні методи праці тощо.

Підвищення кваліфікації керівних працівників та фахівців проводиться для вдосконалення знань, умінь та навичок за наявною спеціальністю, оволодіння функціональними обов'язками, основами менеджменту, маркетингу, вдосконалення навичок управління сучасним виробництвом, раціональної та ефективної організації праці тощо.

Підвищення кваліфікації керівних працівників та фахівців може відбуватися як:

- спеціалізація - проводиться для отримання працівником спеціальних знань, умінь та фахових навичок у межах спеціальності, якою він уже володіє;

- довгострокове підвищення кваліфікації - здійснюється залежно від виробничої потреби, але не рідше одного разу на п'ять років;

- короткотермінове підвищення кваліфікації- це поглиблене вивчення керівними працівниками та фахівцями підприємства певного напряму діяльності;

- стажування - проводиться на підприємствах як в Україні, так і за їі межами задля того, щоб працівники засвоїли вітчизняний і зарубіжний досвід та набули практичних умінь і навичок для виконання обов'язків на посаді або на посаді вищого рівня.

Вищенаведена інформація свідчить про те, що підвищення кваліфікації $\epsilon$ процесом, який демонструє комплекс заходів, що стимулюють професійну мобільність індивіда задля професійного зростання, впровадження нових технік і технологій, освоєння новітніх машин і механізмів, методів ефективного управління тощо. Детальніше дослідження процесу підвищення кваліфікації як способу формування професійної мобільності потребує вивчення внутрішніх потреб фахівця, його здібностей, визначення змісту додаткової професійної освіти 3 урахуванням рівня теоретичних і практичних знань, умінь і навичок фахівця, а також ступеня самоусвідомлення особистістю своєї професійної мобільності. Кожен 3 цих складників містить у собі підструктури, розвиток яких приведе до свідомого формування та стимулювання соціально-професійної мобільності працівників.

Нами було проведено анкетування під час проведення курсів підвищення кваліфікації навчально-курсовим центром Інституту професійного росту фахівців туризму і курортів серед працівників туристичних підприємств (126 осіб), готельного господарства (254 особи) та викладачів навчальних закладів туристичного профілю (75 осіб) задля виявлення особистісної готовності до саморозвитку, що свідчить про рівень їх соціальної мобільності [1, с. 37-38].

У результаті опитування 3'ясувалось, що $95 \%$ викладачів вищих навчальних закладів, 85 \% працівників туристичних підприємств, 65 \% працівників готельного господарства виявили бажання займатись своїм професійним розвитком. Однак, усі без винятку посилались на ті чи інші проблеми, що перешкоджають цьому (табл. 1).

Аналіз наведених досліджень свідчить, що професійному зростанню більшості респондентів перешкоджає: відсутність підтримки з боку керівництва, особистісне неприйняття сучасних змін та професійна інертність, конкуренція між працівниками тощо.

Отже, водночас із готовністю до професійної мобільності працівники сфери туризму свідомо або несвідомо гальмують процес професійного росту, з тривогою очікують зміни, що можуть відбутись в результаті навчання на курсах підвищення кваліфікації та підсумкового моніторингу знань та вмінь працівників. 
Таблиця 1.

Аналіз причин, що перешкоджають професійному саморозвитку

\begin{tabular}{|l|c|c|c|}
\hline $\begin{array}{c}\text { Причини, що } \\
\text { перешкоджають } \\
\text { проф. саморозвитку }\end{array}$ & $\begin{array}{c}\text { Працівники } \\
\text { турфірм (\%) }\end{array}$ & $\begin{array}{c}\text { Працівники } \\
\text { гот. госп. (\%) }\end{array}$ & $\begin{array}{c}\text { Викладачі } \\
\text { ВН3 (\%) }\end{array}$ \\
\hline Власна інертність & 17 & 35 & 25 \\
\hline $\begin{array}{l}\text { Відсутність підтримки } 3 \\
\text { боку керівництва }\end{array}$ & 54 & 41 & 33 \\
\hline Ворожість оточуючих & 33 & 66 & 70 \\
\hline Несприйняття змін & 67 & 34 & 32 \\
\hline Нестача часу & 35 & 40 & 25 \\
\hline
\end{tabular}

Дійсно, до складників професійної мобільності фахівця належать: професійні компетентності (ключові і загальнопрофесійні), готовність особистості до швидкого реагування в момент нестандартних виробничих ситуацій, до сприйняття технічних, технологічних, соціальних, психологічних, організаційних змін, здатність до прогнозування професійної самореалізації, професійна i соціальна активність, життєвий і професійний досвід [6, с. 135].

Професійна мобільність як складний конструкт одночасно характеризує:

1) якість особистості, яка забезпечує внутрішній механізм розвитку людини через сформованість ключових загально професійних компетенцій;

2) діяльність людини, що детермінована подіями, які змінюють середовище, результатом чого постає самореалізація людини у професії й житті;

3) процес перетворення людиною самої себе й оточуючого іiї професійного й життєвого середовища [3, с. 27].

Готовність до професійної мобільності у фахівців виявляється як на організаційно-мотиваційному, так і на підсумковому етапі підвищення кваліфікації. На організаційно-мотиваційному етапі розв'язуються такі завдання: формування у фахівців мотивів підвищення кваліфікації; розвиток потреб та стійкості емоцій, прагнень, бажань стосовно оволодіння системою фахових знань, необхідних для набуття високого рівня кваліфікації; усвідомлення важливості підвищення кваліфікації для успішної професійної діяльності.

Зміст організаційно-мотиваційного етапу підвищення кваліфікації передбачає: знайомство викладачів зі слухачами, проведення попереднього тестування задля наявних професійних знань та вмінь; ознайомлення викладачів 3 матеріальнотехнічною базою підприємства та умовами проведення теоретичних і практичних занять курсів підвищення кваліфікації; корегування навчальних планів з урахуванням побажань слухачів курсів (побажання керівників підприємства та його структурних підрозділів враховуються на етапі укладання угоди про підвищення кваліфікації); ознайомлення слухачів курсів 3 навчальними планами та програмами, формами організації навчального процесу; складання графіку роботи курсів підвищення кваліфікації, проведення теоретичних і практичних занять; визначення форми моніторингу одержаних у процесі підвищення кваліфікації знань і умінь.

Кожен 3 працівників, що приступає до навчання на курсах підвищення кваліфікації, з одного боку, очікує одержати пізнавальні, матеріальні, моральні преференції, а з іншого - впевнений, що у своій роботі він знає майже все і нічого нового не почує. Завдання викладача сформувати прагнення до нових знань, більш 
того - готовність їх сприймати і застосовувати на виробництві, тобто прагнути до професійної мобільності. На нашу думку, саме так слід розуміти поняття «професійна мобільність»: це не тільки професійне зростання, прагнення до саморозвитку, а ще й відкритість до сприйняття нової інформації, бажання покращити виробничі показники, виготовляти якісну продукцію чи надавати якісні послуги.

Отже, сучасний ринок праці потребує висококваліфікованих професійномобільних фахівців з розвинутою креативністю, здатних критично мислити і тих, що мають когнітивні здібності. Саме професійна мобільність фахівців дає можливість максимально ефективно використовувати результати підвищення кваліфікації фахівців будь-якої галузі.

1. Грибова Л. В. Організаційно-методичні засади підвищення кваліфікації фахівців сфери туризму: дис. ... кандидата пед. наук: 13.00.04. / Грибова Людмила Володимирівна. - Вінниця, 2010. - 181 с. 2. Гринько В. О. Емпіричне дослідження складових професійної мобільності викладача вищої школи / В. О. Гринько // Збірник наукових праць КПНУ імені Івана Огієнка, Інституту психології ім. Г. С. Костюка НАПН України // Проблеми сучасної психології. - 2011. - Вип. 14. - С. 134-143. 3. Добрышина Е. В. Профессиональная мобильность как один из критериев качества образования [Электронный ресурс]/ Е. В. Добрышина. - Режим доступа : http://h.kubstu.ru/juk/vipusk6.htm 4. Наказ Міністерства праці та соціальної політики та Міністерства освіти і науки України «Про затвердження Положення про професійне навчання кадрів на виробництві» від 27 березня 2001 року № 127/151 5. Сорокин П. А. Социальная мобильность // Человек. Цивилизация. Общество/ Общ. ред. сост. и предисл. А. Ю. Согомонова. - [пер. с англ.]. - М. : Политиздат, 1992. 543 с. 6. Професійна мобільність як сучасна педагогічна проблема [Текст]/ Л. Л. Сушенцева // Креативна педагогіка : наук.-метод. журнал. - 2011. - Вип. 1. С. 129-136. 7. Професійна освіта: Словник: [навч. посіб.] / Уклад. С. У. Гончаренко та ін.; за ред. Н. Г. Ничкало. - К. : Вища школа, 2000. - 380 с.

УДК 372.461

Артур Іншаков

\section{ДІЯЛЬНІСНИЙ ПІДХІД ДО ОРГАНІЗАЦІЇ СЛОВНИКОВОЇ РОБОТИ З ДІТЬМИ СТАРШОГО ДОШКІЛЬНОГО ВІКУ}

Іншаков А. Є. Діяльнісний підхід до організації словникової роботи 3 дітьми старшого дошкільного віку.

У статті розкрито шляхи реалізації діяльнісного підходу до організації словникової роботи 3 дітьми старшого дошкільного віку. Схарактеризовано мовленнєву діяльність дошкільнят під час формування й поглиблення словника. Наведено зразки вправ, які сприяють збагаченню словника дошкільнят у процесі художньо-мовленнєвої діяльності.

Ключові слова: діяльнісний підхід, діти дошкільного віку, словникова робота, мовленнєва діяльність, художньо-мовленнєва діяльність.

Иншаков А. Е. Деятельностный подход к организации словарной работы с детьми старшего дошкольного возраста.

В статье раскрыты пути реализации деятельностного подхода к организации словарной работы с детьми старшего дошкольного возраста. Охарактеризована речевая деятельность дошкольников при формировании и углублении словаря. 